\title{
SOFT INNOVATION RESOURCES: ENABLER FOR REVERSAL IN GDP GROWTH IN THE DIGITAL ECONOMY
}

\author{
Yuji Tou ${ }^{1}$, Kuniko Moriya ${ }^{2,3}$, Chihiro Watanabe ${ }^{4,5}$, Leena Ilmola ${ }^{6}$, Pekka \\ Neittaanmäki ${ }^{7}$
}

${ }^{1}$ Dept. of Ind. Engineering \& Magm., Tokyo Institute of Technology, Tokyo, Japan

${ }^{2}$ Research and Statistics Department, Bank of Japan, Tokyo, Japan

${ }^{3}$ Faculty of Information Technology, University of Jyväskylä, Finland

${ }^{4}$ Faculty of Information Technology, University of Jyväskylä, Finland

${ }^{5}$ International Institute for Applied Systems Analysis (IIASA), Austria

${ }^{6}$ International Institute for Applied Systems Analysis (IIASA), Austria

${ }^{7}$ Faculty of Information Technology, University of Jyväskylä, Finland

\begin{abstract}
While Finland and Singapore have been maintaining world digital leaders position, they demonstrate interlaced contrast: high welfare with low GDP growth in Finland and higher GDP growth with lower welfare in Singapore. This provokes an uncaptured GDP postulate that Finnish wellbeing has developed more than one might conclude by GDP. However, a recent reversal in the GDP growth trend suggests the possibility that uncaptured GDP contributes to remove structural impediments in GDP growth.This paper demonstrates this hypothesis. An empirical analysis elucidating the inside the national accountings and institutional systems revealed that soft innovation resources have substituted for service capital in Finland and created uncaptured GDP which disseminated in tangible capital and removed structural impediments impeding development leading to GDP growth. In addition, this growth enables next generation intellectual property product (IPP) development. An insightful suggestion in overcoming a productivity paradox in the digital economy was thus provided.
\end{abstract}

\section{KEYWORDS}

Digital economy, soft innovation resources, structural impediments in growth, productivity paradox, Finland and Singapore

\section{INTRODUCTION}

Digital economy transforms the traditional concepts of economic growth. While Finland and Singapore have been maintaining world digital leaders position, both countries demonstrated a contrasting structure. Finland enjoyed high level of happiness/welfare under the great stagnation while Singapore accomplished conspicuously high economic growth in the lower level of happiness/welfare. This observation prompts us a hypothetical view that "well-being of the Finnish people has developed in a more positive direction than one might conclude by GDP data" [1]. 
International Journal of Managing Information Technology (IJMIT) Vol.10, No.3, August 2018

Furthermore, the recent reversal trend in GDP growth in two countries (Fig. 1) suggests a possibility of a transformation of the traditional concepts of GDP growth [2].

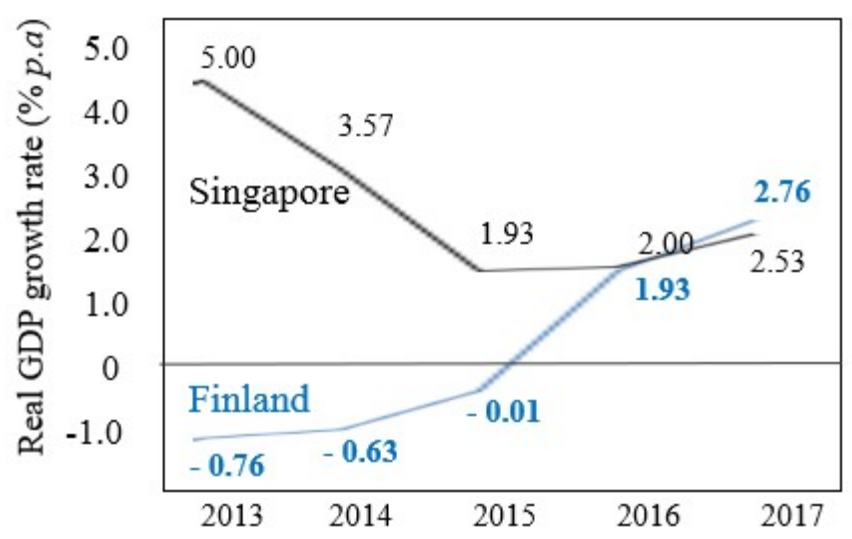

Source: [3].

Figure. 1. Recent reversal trend in GDP growth of digital leaders (2013-2017).

Confronting a productivity decline in the digital economy, global ICT leaders are transforming business models into those with uncaptured GDP creation for their survival. This can be attributed to the harnessing soft innovation resources against a productivity decline. This in turn activates a self-propagating function and induces supra-functionality beyond economic value corresponding to a shift in people's preferences [4].

Authors demonstrated that this dynamism also contributes to removing structural impediments in GDP growth, thus uncaptured GDP dependence by harnessing soft innovation resources contributes to overcoming economic stagnation by its hybrid functions [2].

They then postulated that the recent reversal trend in GDP growth of ICT leaders Finland and Singapore can be attributed to this contribution, and attempted to demonstrate this hypothetical view.

They first identified that Finland's recent GDP growth recovery can largely be attributed to its gross fixed capital formation to which negative contribution in Singapore as demonstrated in Table 1.

They then identified that contrary to increasing share in Singapore, Finland has been shifting to less dependent on intellectual property products (IPP) in its gross fixed capital formation as demonstrated in Fig. 2. 
International Journal of Managing Information Technology (IJMIT) Vol.10, No.3, August 2018

Table 1. Contribution to expenditure on GDP growth in Finland and Singapore (2013 - 2017) - real growth rate $(\% p . a)$.

\begin{tabular}{|l|c|c|c|c|c|}
\hline \multicolumn{1}{|c|}{ Finland } & 2013 & 2014 & 2015 & 2016 & 2017 \\
\hline Private consumption & -2.09 & 0.11 & 1.50 & 0.83 & 0.96 \\
\hline Govemment consumption & 2.28 & 0.00 & 0.10 & 0.37 & 0.32 \\
\hline Gross fixed capital & -9.50 & -0.11 & 0.20 & $\mathbf{1 . 1 9}$ & $\mathbf{1 . 4 9}$ \\
\hline Net exports of goods and services & 8.45 & -0.63 & -1.98 & -0.18 & 0.53 \\
\hline Others (inventories and net acquisitions of variables) & 0.10 & 0.00 & 0.17 & -0.28 & -0.54 \\
\hline \multicolumn{1}{|c|}{ Total } & $\mathbf{- 0 . 7 6}$ & $\mathbf{- 0 . 6 3}$ & $\mathbf{- 0 . 0 1}$ & $\mathbf{1 . 9 3}$ & $\mathbf{2 . 7 6}$ \\
\hline
\end{tabular}

Original source: [5].

\begin{tabular}{|l|c|c|c|c|c|}
\hline \multicolumn{1}{|c|}{ Singapore } & 2013 & 2014 & 2015 & 2016 & 2017 \\
\hline Private consumption & 1.27 & 1.37 & 1.40 & 0.33 & 0.98 \\
\hline Govemment consumption & 0.98 & 0.00 & 0.61 & 0.17 & 0.35 \\
\hline Gross fixed capital & 1.67 & 1.74 & 0.44 & $\mathbf{- 0 . 0 8}$ & $\mathbf{- 0 . 4 2}$ \\
\hline Net exports of goods and services & 1.27 & 1.56 & 1.58 & 0.92 & -0.56 \\
\hline Others (inventories and net acquisitions of variables) & -0.19 & -1.10 & -2.10 & 0.66 & 2.18 \\
\hline \multicolumn{1}{|c|}{ Total } & $\mathbf{5 . 0 0}$ & $\mathbf{3 . 5 7}$ & $\mathbf{1 . 9 3}$ & $\mathbf{2 . 0 0}$ & $\mathbf{2 . 5 3}$ \\
\hline
\end{tabular}

Original source: [6].

Adjusted to IMF statistics using the share of respective contribution by respective statistics.



Figure 2. Trends in share of intellectual property products (IPP) out of gross fixed capital formation in Finland and Singapore (2006-2017) - \%.

Sources: Same as original sources of Table 1. Finland 2017 value is estimated based on the trend in 20142016. 
International Journal of Managing Information Technology (IJMIT) Vol.10, No.3, August 2018

Recalling recent noteworthy improvements in Finland on the effective utilization of soft innovation resources such as trust (e.g., government-labor union reform pact in June 2016) and untapped resources utilization (e.g., female business executives increase through gender balance improvement), they interpreted these contrasting trajectories in two digital leaders as higher dependence on soft innovation resources rather on ICT R\&D in Finland and cling to ICT R\&D in Singapore. However, no substantial evidences has provided to this interpretation.

This paper attempts to demonstrate this hypothetical interpretation.

Following up the preceding analysis and insights obtained thereon, this paper attempts further elucidation of the hybrid role of soft innovation resources-driven uncaptured GDP creation. Spontaneous creation of this uncaptured GDP satisfies a shift in people's preferences to suprafunctionality beyond economic value and also removes structural impediments in GDP growth.

On the basis of an empirical analysis elucidating the inside the national accountings and institutional systems it was revealed that soft innovation resources have substituted for service capital (IPP) in Finland and created uncaptured GDP which disseminated in tangible capital and removed structural impediments impeding its formation. This formation leads to GDP growth. In addition, this growth enables next generation IPP development.

Fig. 3 illustrates framework of the demonstration of this hypothetical view.

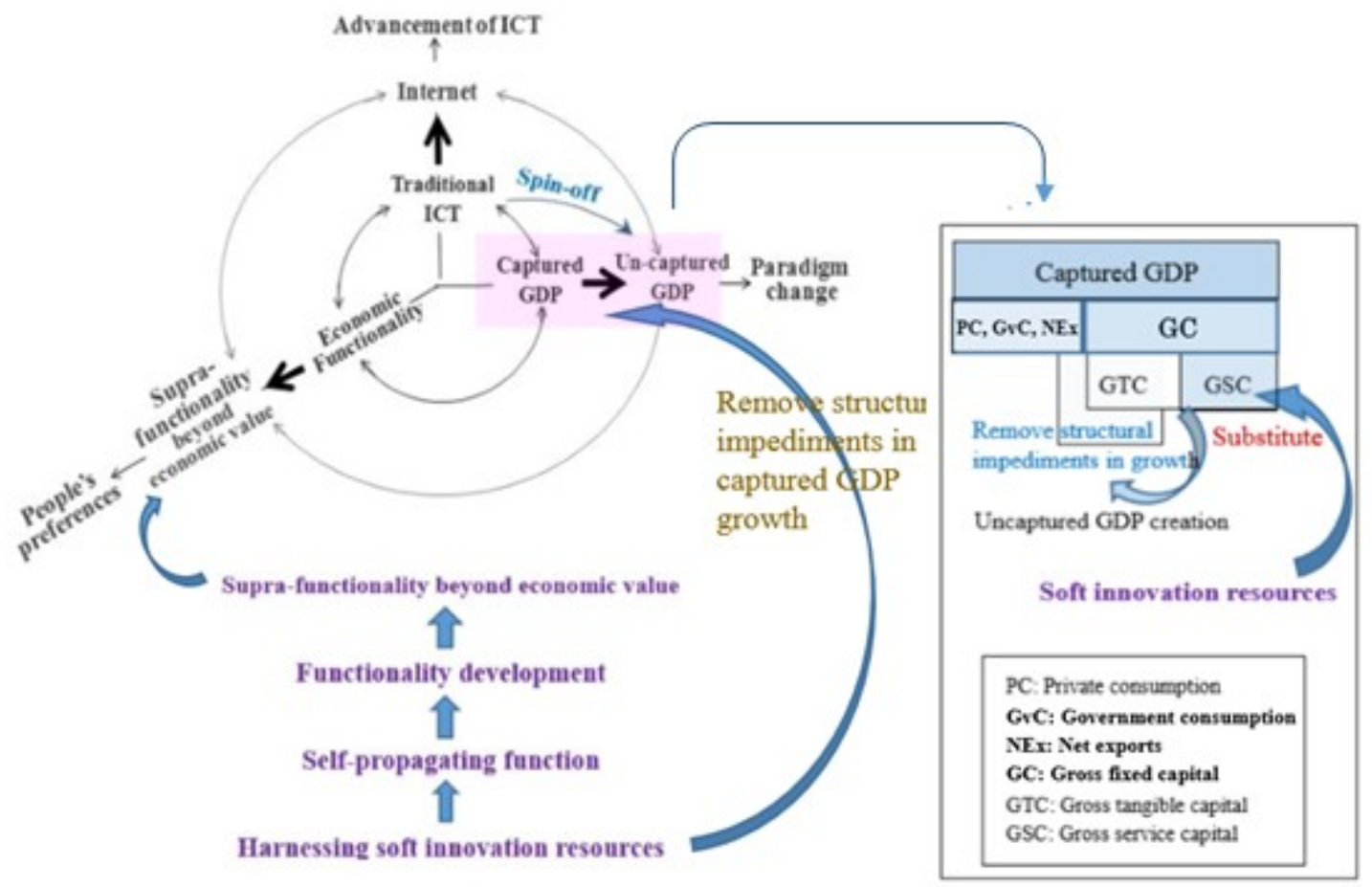

Figure 3. Dynamism of hybrid role of soft innovation resources: Creation of uncaptured GDP and remove structural impediments in captured GDP growth.

An insightful suggestion to a productivity paradox in the digital economy was thus provided. 
International Journal of Managing Information Technology (IJMIT) Vol.10, No.3, August 2018

Section 2 analyzes contributor to capital increase. Role of soft innovation resources is reviewed in Section 3. Section 4 demonstrates soft innovation resources substitution for IPP. Section 5 analyzes effects of dissemination of soft innovation resources in tangible capital. Section 6 summarizes the noteworthy findings, policy suggestions, and future research.

\section{CONTRIBUtOR To CAPITAL INCREASE}

In light of primal contribution of gross fixed capital formation (GC) to the recent reversal trend in GDP growth between Finland and Singapore as demonstrated in Table 1, contributor of GC growth was analyzed by dividing GC into gross service capital (GSC) and gross tangible capital (GTC). Here, GSC is represented by IPP in the national accounts while GTC includes such tangible assets as machinery, vehicles, plant, dwellings, buildings, and land improvements.

Table 2 compares focus of respective resources.

Table 2. Focus of gross capital investment and possible substitution by soft innovation resources

\begin{tabular}{|l|l|l|}
\hline Gross service capital & Gross tangible capital & \multicolumn{1}{|c|}{ Soft innovation resources } \\
\hline R\&D & Machinery & Driving force of preferences shift to \\
Software and data & Vehicles & supra-functionality \\
bases & Plant & Sleeping resources \\
Mineral exploration & Dwellings & Trust by overdrawing past information \\
and evaluation & Buildings & Utmost gratification ever experienced \\
Entertainment, literary & structures & Memory and future dream \\
or artistic originals & Land improvements & Untapped resources and vision \\
\hline
\end{tabular}

$G C$ can be decomposed as follow:

$G C=\kappa G C+\lambda G C$

where $\kappa$ and $\lambda$ : share of $G S C$ and $G T C$, respectively. $\kappa+\lambda=1$

Differentiate by time $t$ :

$\frac{d G C}{d t}=\Delta G C=(\Delta \kappa \cdot G C+\kappa \cdot \triangle G C)+(\Delta \lambda \cdot G C+\lambda \cdot \triangle G C)$

Thus, growth rate can be depicted as follows:

$\frac{\triangle G C}{G C}=\left(\triangle \kappa+k \cdot \frac{\triangle G C}{G C}\right)+\left(\triangle \lambda+\lambda \cdot \frac{\triangle G C}{G C}\right)$

Table 3 compares contribution of $G S C$ and $G T C$ to $G C$ growth rate in Finland and Singapore over the period 2013-2017. Fig. 4 compares contribution of $G T C$ to $G C$ in two countries.

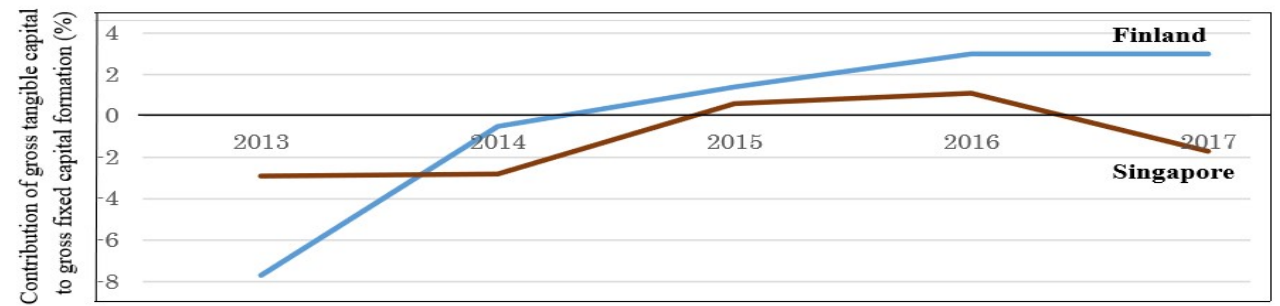

Figure 4. Trend in gross tangible capital $(G T C)$ contribution to gross fixed capital $(G C)$ formation in Finland and Singapore (2013-2017). 
International Journal of Managing Information Technology (IJMIT) Vol.10, No.3, August 2018

Looking at this figure we note that while Finland has been shifting from dependence on gross $G S C$ to $G T C$ for its $G C$ formation, Singapore has been clinging to GSC. This suggests that soft innovation resources substitute for GSC and induce GTC in Finland that leads its GDP growth.

Table 3. Contribution of growth rate of gross fixed capital $(G C)$ formation in Finland and Singapore (20132017) $-\%$.

\begin{tabular}{|c|c|c|c|c|c|c|}
\hline & & & & & & \\
\hline & & 2013 & 2014 & 2015 & 2016 & 2017 \\
\hline \multirow{7}{*}{ 䓌 } & $\kappa$ & 21.7 & 22.1 & 20.9 & 18.8 & $17.0^{*}$ \\
\hline & $\lambda$ & 78.3 & 77.9 & 79.1 & 81.2 & $83.0^{*}$ \\
\hline & $\frac{\Delta G C}{G C}$ & -9.50 & -0.11 & 0.20 & 1.19 & 1.49 \\
\hline & $\Delta \kappa$ & 0.3 & 0.4 & -1.2 & -2.1 & -1.8 \\
\hline & $\Delta \lambda$ & -0.3 & -0.4 & 1.2 & 2.1 & 1.8 \\
\hline & $\Delta \kappa+\kappa \frac{\Delta G C}{G C}$ & -1.8 & 0.4 & -1.2 & -1.8 & -1.5 \\
\hline & $\Delta \lambda+\lambda \frac{\Delta G C}{G C}$ & -7.7 & -0.5 & 1.4 & 3.0 & 3.0 \\
\hline \multirow{7}{*}{$\begin{array}{l}\text { 总 } \\
\text { 总 } \\
\text { 品 }\end{array}$} & $\kappa$ & 18.9 & 23.2 & 22.7 & 21.5 & 22.9 \\
\hline & $\lambda$ & 81.1 & 76.8 & 77.3 & 78.5 & 77.1 \\
\hline & $\frac{\Delta G C}{G C}$ & 1.67 & 1.74 & 0.44 & -0.08 & -0.42 \\
\hline & $\Delta \kappa$ & 4.3 & 4.3 & -0.3 & -1.2 & 1.4 \\
\hline & $\Delta \lambda$ & -4.3 & -4.3 & 0.3 & 1.2 & -1.4 \\
\hline & $\Delta \kappa+\kappa \frac{\Delta G C}{G C}$ & 4.6 & 4.5 & -0.2 & -1.2 & 1.3 \\
\hline & $\Delta \lambda+\lambda \frac{\Delta G C}{G C}$ & -2.9 & -2.8 & 0.6 & 1.1 & -1.7 \\
\hline
\end{tabular}

* indicates estimate based on the trend in 2014-2016.

\begin{tabular}{|c|c|c|c|c|c|c|}
\hline \multirow{2}{*}{\multicolumn{2}{|c|}{ GTC contribution to GDP ( $\%$ p.a $)$}} & \multirow{3}{*}{$\begin{array}{c}2013 \\
-0.76\end{array}$} & \multirow{3}{*}{$\begin{array}{c}2014 \\
-0.63\end{array}$} & \multirow{3}{*}{$\begin{array}{c}2015 \\
-0.01\end{array}$} & \multirow{3}{*}{$\begin{array}{l}2016 \\
1.93\end{array}$} & \multirow{3}{*}{$\begin{array}{l}2017 \\
2.76 \\
\end{array}$} \\
\hline & & & & & & \\
\hline \multirow{4}{*}{ 㿣 } & GDP & & & & & \\
\hline & GC contribution to GDP & -9.50 & -0.11 & 0.20 & 1.19 & 1.49 \\
\hline & GSC contribution to GC & -1.80 & 0.40 & -1.20 & -1.81 & -1.51 \\
\hline & GTC contribution to GC & -7.70 & -0.51 & 1.40 & 3.00 & 3.00 \\
\hline \multirow{4}{*}{ 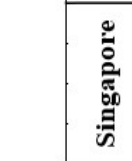 } & GDP & 5.00 & 3.57 & 1.93 & 2.00 & 2.53 \\
\hline & GC contribution to GDP & 1.67 & 1.74 & 0.44 & -0.08 & -0.42 \\
\hline & GSC contribution to GC & 4.57 & 4.54 & -0.16 & -1.18 & 1.28 \\
\hline & GTC contribution to GC & -2.90 & -2.80 & 0.60 & 1.10 & -1.70 \\
\hline
\end{tabular}

\section{Role OF SOFT INNOVATION RESOURCES}

\subsection{SOFT INNOVATION RESOURCES}

Confronting productivity decline in the digital economy, leading global ICT firms have been endeavoring to transform into a new business model that creates supra-functionality beyond economic value corresponding to a shift in people's preferences by not largely depending on R\&D investment which may accelerate productivity decline [7]. 
International Journal of Managing Information Technology (IJMIT) Vol.10, No.3, August 2018

Against such circumstances, highly R\&D intensive firms endeavor to effective utilization of soft innovation resources rather than depending on further ICT R\&D as demonstrated in Fig. 5 [7] [8]. Soft innovation resources activate potential of self-propagating function indigenous to ICT (see Note) which induces functionality development leading to supra-functionality creation.

Note: ICT in which network externalities function to alter the correlation between innovation and institutional systems which creates new features of the innovation leading to exponential increase in a self-propagating way [9].

Note: ICT in which network externalities function to alter the correlation between innovation and institutional systems which creates new features of the innovation leading to exponential increase in a self-propagating way [9].

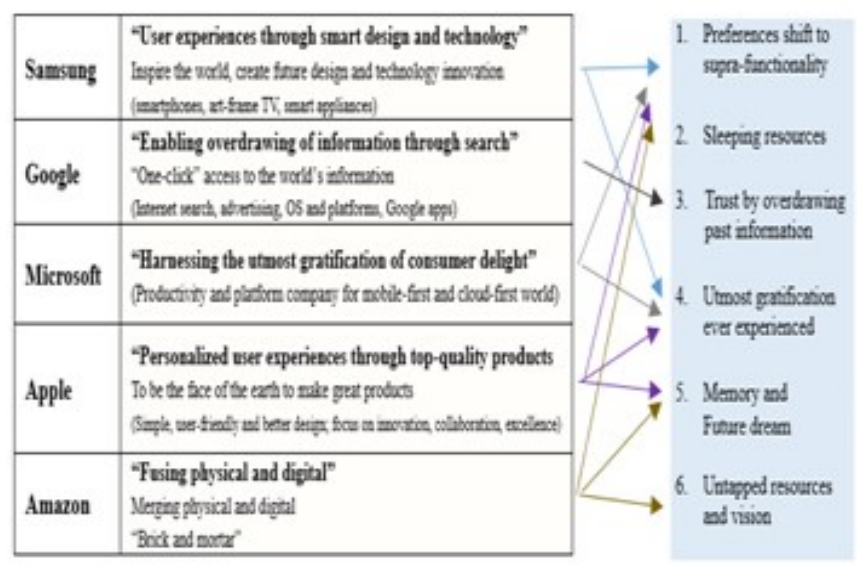

\begin{tabular}{|l|l|l|}
\hline \multicolumn{1}{|c|}{$\begin{array}{c}\text { Past } \\
\text { PoT) }\end{array}$} & \multicolumn{1}{|c|}{$\begin{array}{c}\text { Current } \\
\text { (loT) }\end{array}$} & \multicolumn{1}{c|}{$\begin{array}{c}\text { Future } \\
\text { (Beyond IoT) }\end{array}$} \\
\hline $\begin{array}{l}\text { Economic } \\
\text { functionality }\end{array}$ & Supra-functionality & $\begin{array}{l}\text { Digital } \\
\text { supra-functionality }\end{array}$ \\
\hline $\begin{array}{l}\text { Sleeping } \\
\text { res ources }\end{array}$ & $\begin{array}{l}\text { Trestbused tri-partism } \\
\text { cooperation }\end{array}$ & $\begin{array}{l}\text { Auboomos electromic } \\
\text { trunsportation system }\end{array}$ \\
\hline $\begin{array}{l}\text { Knowledge } \\
\text { and experiences }\end{array}$ & $\begin{array}{l}\text { Overdrawing past } \\
\text { information }\end{array}$ & $\begin{array}{l}\text { Brain computer } \\
\text { interfaces }\end{array}$ \\
\hline $\begin{array}{l}\text { Utmost } \\
\text { gratification } \\
\text { ever experiencod }\end{array}$ & $\begin{array}{l}\text { Conceptualization } \\
\text { of invisiblevoice } \\
\text { of consumers }\end{array}$ & $\begin{array}{l}\text { Commodification } \\
\text { of experiences }\end{array}$ \\
\hline $\begin{array}{l}\text { Past unforgettable } \\
\text { nemories and } \\
\text { xperiences }\end{array}$ & $\begin{array}{l}\text { Invoking } \\
\text { memories, } \\
\text { Synchronizing } \\
\text { future dream }\end{array}$ & $\begin{array}{l}\text { Virtual } \\
\text { participation }\end{array}$ \\
\hline $\begin{array}{l}\text { Limited } \\
\text { participation } \\
\text { and } \\
\text { opportunity }\end{array}$ & $\begin{array}{l}\text { Harnes sing the } \\
\text { vigor of untapped } \\
\text { resources }\end{array}$ & $\begin{array}{l}\text { Ambitious vision } \\
\text { for harnessing } \\
\text { untapped } \\
\text { resources }\end{array}$ \\
\hline
\end{tabular}

Figure 5. Soft innovation resources initiated by global ICT firms' pioneering endeavor.

\subsection{The Role Of The Internet For Harnessing The Vigour Of Soft INNOVATION RESOURCES}

Soft innovation resources can be emerged by harnessing the vigor of non-monetary function such as:

(i) Driving force of co-evolutionary dynamism among the Internet advancement, uncaptured GDP dependence and a shift in people's preferences to supra-functionality beyond economic value (Fig. 6-1).

(ii) Sleeping resources as non-operational cars and drivers as well as idling time which can be awoken and utilized effectively by means of the Internet and smartphones (Fig. 6-2).

(iii) Trust by overdrawing past information which can be accelerated by the Internet (Fig. 6-3).

(iv) Utmost gratification ever experienced leading to consumption which effectively recalled by the Internet (Fig. 6-4).

(v) Memory and dream recalled and drawn actively by the Internet (Fig. 6-5).

(vi) Untapped resources effectively utilized and envisioned by the Internet (Fig. 6-6). 
International Journal of Managing Information Technology (IJMIT) Vol.10, No.3, August 2018

All can largely be depended on the advancement of the Internet and further activated toward the IoT society [10] [11] [12].

Fig. 6 outlines dynamism of typical soft innovation resources in activating self-propagating function.
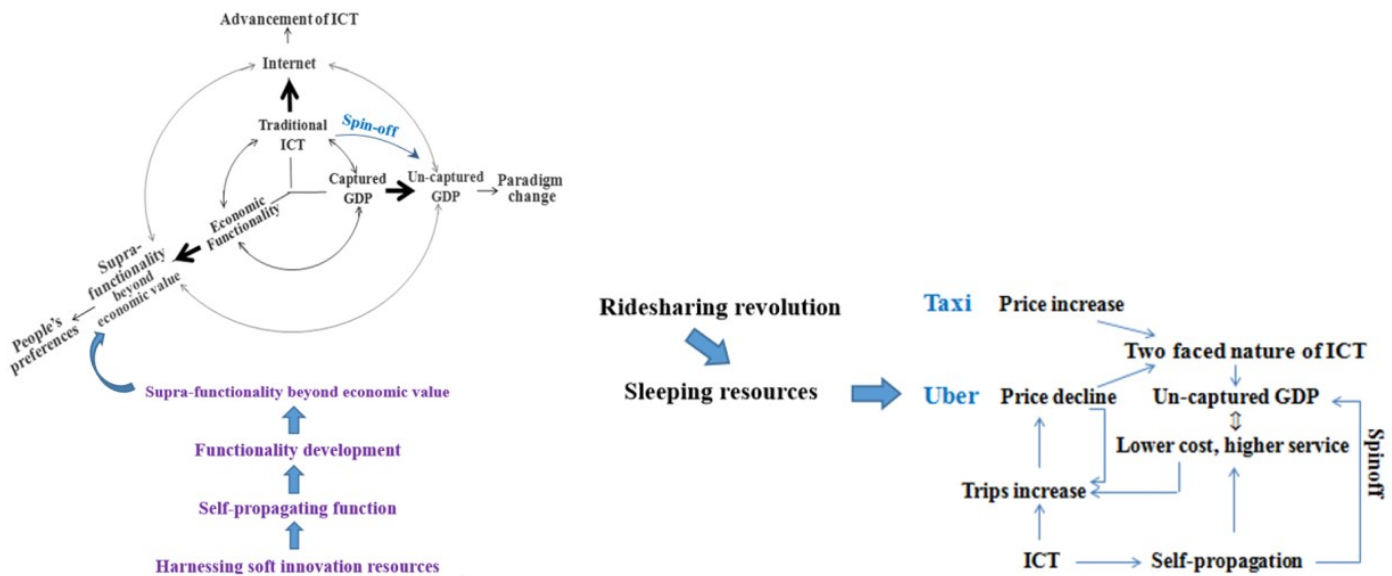

Fig. 6-1. Driving force of co-evolutionary dynamism.

Fig. 6-2. Sleeping resources. Source: [4].

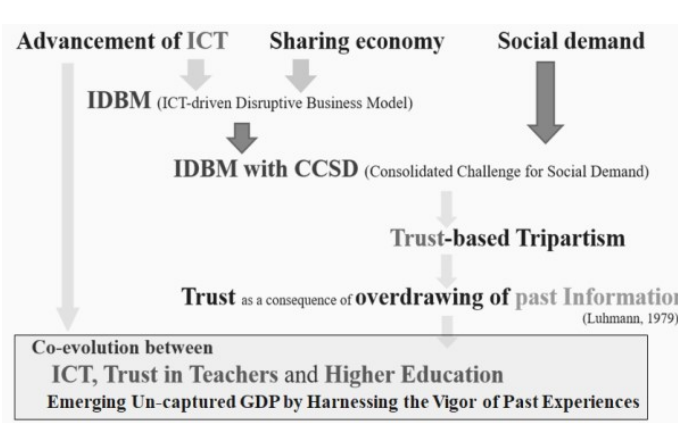

Fig. 6-3. Trust by overdrawing past innovation. Source: [14].



Fig. 6-5. Memory and future dream. Source: [16].

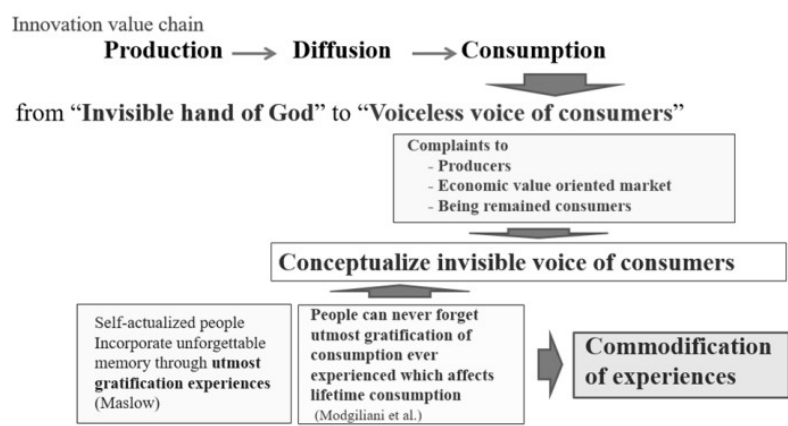

Fig. 6-4. Utmost gratification ever experienced. Source: [15].

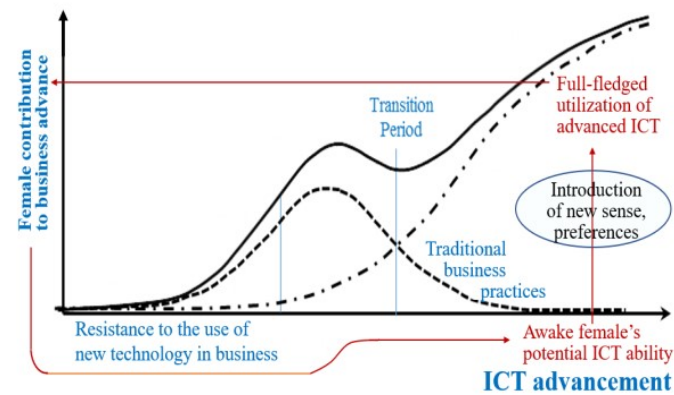

Fig. 6-6. Untapped resources and vision. Source: [17]. 
International Journal of Managing Information Technology (IJMIT) Vol.10, No.3, August 2018

\section{Soft InNOVATION Resources SubSTitute For IPP 4.1. BURDEN OF R\&D INVESTMENT}

Figs. 7 and 8 compare trends in R\&D expenditure between Finland and Singapore over the period 1994-2016 by decomposing business enterprise R\&D and government R\&D.

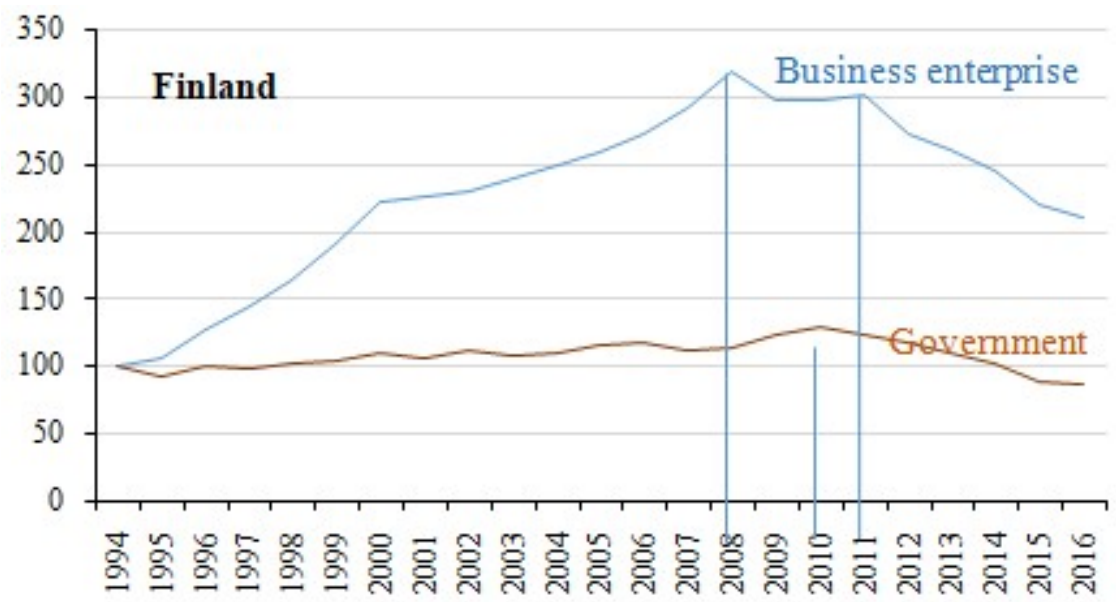

Figure 7. Trend in R\&D by source of funding in Finland (1994-2016) - Index: $1994=100$. Source: [18].

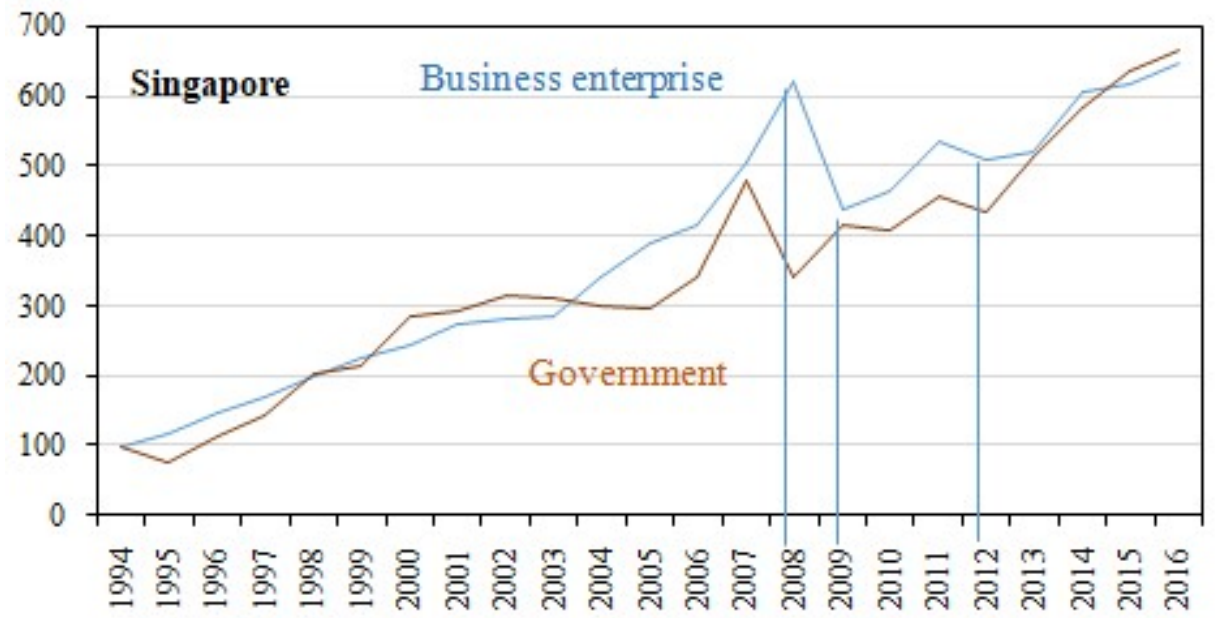

Figure 8. Trend in R\&D by source of funding in Singapore (1994-2016) - Index: $1994=100$.

Source: [19].

Note: 2015 and 2016 values are estimated by [6] and [20].

While both leaders experienced sharp decrease in their R\&D investment both government and business enterprise after the Lehman shock in 2008. However, contrary to Singapore's prompt recovery from 2010 under strong government initiative, Finland suffered longer stagnation both in government and business enterprise.

In Finland, while business-funding R\&D started to decline due to the Lehman shock in 2008, government funding of R\&D continued to grow. However, it switched from expansionary to 
International Journal of Managing Information Technology (IJMIT) Vol.10, No.3, August 2018

contractionary policy after 2010 which exacerbated a massive drop in business-funded R\&D [21]. Consequently, growth rate of gross service capital (IPP) has shown decreasing trend in Finland from 2010 as demonstrated in Fig. 2. While government contractionary policy continued till 2015 and slightly relaxed from 2016 corresponding to the nation's economic resurgence, Finland R\&D funding continued to decline with clear contrast in Singapore's sharp increase.

Given the increasing burden of traditional ICT R\&D investment (which shares the majority of IPP) while its productivity has been declining as a consequence of the two-faced nature of ICT [22], Finland has been considering to substitute IPP to soft innovation resources which create new functionality corresponding to a shift in people's preferences to supra-functionality beyond economic value with smaller capital investment [7]. This corresponds to spontaneous creation of uncaptured GDP initiated in the forefront of global ICT firms endeavor amidst the digital economy [7].

In "Finland's National Innovation Strategy" published in 2008 [23] following fundamental concepts were introduced:

- Finland's success has largely been based on its high-quality education system, long-term investments by enterprises and the public sector in $\mathrm{R} \& \mathrm{D}$, and its well-functioning, networked institutions.

- The challenges of growth and competitiveness can no longer be tackled only by means of a sector-based, technology-oriented strategy, instead, a demand-based innovation policy must be strengthened alongside a supply-based innovation policy.

- Innovation emerges as a combination of many competencies. Broad-based innovation policy creates the preconditions for operating models combining the needs of users, consumers and citizens, alongside knowledge, creativity and competence.

- Demand and user orientation are required to attain Finnish strategic goals: Innovation steered by demand, playing attention to the needs of customers, consumers and citizens in the operation of the public and private sector alike, requires a market with incentives and shared innovation processes between users and developers.

- There is room for improvement in Finland, particularly as concerns the development and introduction of user-oriented service innovations.

- The success of innovative communities is based on sharing competence and knowledge, and the ability to combine different perspectives and approaches. Increasingly often, innovations are created on the interfaces of various competence areas.

- The connections between producers and users of information are exceptionally close in Finland. Generally, Finland's innovation enterprises corporate with other parties exceptionally often.

- A systematic approach is the key concept in implementing a broad-based innovation policy. New incentives accelerate changes of perspective in the innovation precesses, bringing individuals as end users into the core of innovation activity. Therefore, the innovation 
International Journal of Managing Information Technology (IJMIT) Vol.10, No.3, August 2018 potential of citizens, which previously remained partly hidden, can now be able to capitalized on as the driver of development in the national economy and society.

- Ultimately, pioneering lead markets will be created on the basis of market players' own decisions, but their hoped-for development can be promoted by methodologically implementing measures to support innovative demand.

- Strategic cooperation in assessment, foresight and strategic work across administrative fields will be intensified and precipitated.

Following these fundamental concepts, more concrete action plans for development and utilization of soft innovation resources were proposed in recent years as follows:

- Open platforms for co-creation as Finland is good at visions and roadmaps as a future oriented country [24].

- Use new instruments to link a wide range of actors (knowledge producers, users, intermediaries etc.) in addressing innovation and social challenges [21].

- Finland's national innovation agency TEKES' merge with Finpro from the beginning of 2018 brings Finland's support schemes for research and innovation under one roof and will enable a more networked type of innovation, boosting collaborations between research institutes, universities and companies leading to offering better services for customers and enriching the innovation ecosystem [25].

- Finland considers new business models, products, services and ecosystems enabled by the digital platform economy are included in key issues in the EU's ninth Framework Programme (2021-) for research and innovation. The Programme should enhance measures to include citizens and the civil society in setting and planning the priorities of research and innovation and actual research and innovation activities [26].

- Involving users in the innovation process and providing new impetus to innovation by making use of findings produced by broad stakeholders (Min. of Economic Affairs and Employment [27].

\subsection{Soft InNOVATION RESOURCES SUbSTITUTE FoR IPP}

Given that soft innovation resources are crystal of the advancement of the Internet, as reviewed earlier (Fig. 6), provided that extent of utilization of soft innovation resources is represented by dependence of the Internet, their substitution for IPP can be examined by the following equation:

$\ln \frac{I}{J}=a+\epsilon_{i j} \ln \frac{p_{j}}{p_{i}}$

where $I$ : Internet dependence, $J$ : IPP, $p_{i}$ : Internet price, $p_{j}$ : IPP price, $\epsilon_{i j}$ : elasticity of substitution between Internet and IPP, and $a$ : coefficient.

$\epsilon_{i j}>1, I$ substitutes for $J$ (see Note) 
International Journal of Managing Information Technology (IJMIT) Vol.10, No.3, August 2018

Note $I$ substitution for $J$

$$
\chi \equiv \frac{\text { Internet expenditure }}{I P P \text { expenditure }}=\frac{I \cdot p_{i}}{J \cdot p_{j}} \quad \ln \chi=\ln \frac{I}{J}-\ln \frac{p_{j}}{p_{i}}=a+\left(\epsilon_{i j}-1\right) \ln \frac{p_{j}}{p_{i}}
$$

When $\epsilon_{i j}>1, p_{j}$ increase reacts to Internet expenditure increase ( $I$ substitutes for $J$ )

Table 5 tabulates trends in the Internet, gross service cost (IPP), gross tangible cost and their prices in Finland and Singapore over the period 2000-2017.

\begin{tabular}{|c|c|c|c|c|c|c|c|c|c|c|}
\hline & \multicolumn{2}{|c|}{ Internet dependence } & \multicolumn{2}{|c|}{ GSC/GC $(\kappa)$} & \multicolumn{2}{|c|}{$\mathbf{G T C} / \mathbf{G C}(\lambda)$} & \multicolumn{2}{|c|}{ Internet price } & \multicolumn{2}{|c|}{ IPP price } \\
\hline & $I_{F}$ & $I_{S}$ & $\boldsymbol{J}_{F}$ & $J_{S}$ & $\boldsymbol{K}_{F}$ & $\boldsymbol{K}_{S}$ & $p_{i F}$ & $p_{i S}$ & $p_{j F}$ & $p_{j S}$ \\
\hline 2000 & 100.0 & 100.0 & 100.0 & 100.0 & 100.0 & 100.0 & 100.0 & 100.0 & 100.0 & 100.0 \\
\hline 2001 & 115.7 & 115.8 & 102.7 & 114.6 & 99.2 & 98.5 & 91.6 & 89.5 & 103.7 & 103.3 \\
\hline 2002 & 167.5 & 130.6 & 104.1 & 137.5 & 98.8 & 96.0 & 73.4 & 81.8 & 106.7 & 99.5 \\
\hline 2003 & 185.8 & 149.4 & 107.7 & 154.2 & 97.8 & 94.2 & 69.0 & 73.9 & 108.2 & 101.1 \\
\hline 2004 & 194.4 & 172.2 & 103.6 & 165.6 & 99.0 & 93.0 & 67.1 & 66.5 & 112.4 & 101.2 \\
\hline 2005 & 200.0 & 169.4 & 103.6 & 168.8 & 99.0 & 92.7 & 65.9 & 67.3 & 116.0 & 102.5 \\
\hline 2006 & 213.8 & 163.9 & 103.6 & 180.2 & 99.0 & 91.5 & 63.4 & 69.5 & 119.2 & 104.6 \\
\hline 2007 & 216.8 & 194.2 & 99.5 & 158.3 & 100.1 & 93.8 & 62.9 & 60.8 & 122.4 & 106.7 \\
\hline 2008 & 221.6 & 191.7 & 101.4 & 146.9 & 99.6 & 95.0 & 62.1 & 61.3 & 129.6 & 114.0 \\
\hline 2009 & 224.6 & 191.7 & 109.0 & 156.3 & 97.4 & 94.0 & 61.6 & 61.3 & 134.2 & 110.9 \\
\hline 2010 & 233.2 & 197.2 & 109.0 & 152.1 & 97.4 & 94.5 & 60.2 & 60.1 & 136.7 & 116.1 \\
\hline 2011 & 238.1 & 197.2 & 100.5 & 151.0 & 99.9 & 94.6 & 59.5 & 60.1 & 140.6 & 119.8 \\
\hline 2012 & 241.4 & 200.0 & 96.8 & 152.1 & 100.9 & 94.5 & 59.0 & 59.5 & 144.7 & 121.3 \\
\hline 2013 & 245.5 & 224.7 & 98.2 & 196.9 & 100.5 & 89.7 & 58.3 & 54.4 & 147.8 & 126.8 \\
\hline 2014 & 246.6 & 219.4 & 100.0 & 241.7 & 100.0 & 85.2 & 58.0 & 55.5 & 149.6 & 122.7 \\
\hline 2015 & 248.9 & 219.4 & 94.6 & 236.5 & 101.5 & 85.5 & 57.9 & 55.5 & 151.3 & 129.2 \\
\hline 2016 & 250.7 & 225.0 & 85.1 & 224.0 & 104.2 & 86.8 & 57.6 & 54.4 & 153.6 & 128.9 \\
\hline 2017 & $252.2^{*}$ & $226.4^{*}$ & $80.7^{*}$ & 238.5 & $106.5^{*}$ & 85.3 & $57.4^{*}$ & $54.2^{2}$ & $155.5^{*}$ & 129.9 \\
\hline
\end{tabular}

Table 5. Trends in the Internet, gross service cost, gross tangible cost and their prices in Finland and Singapore (2000-2017) - Index: 2000 $=100$ (F: Finland, $S$ : Singapore)

*Estimated value based on trends in 2014-2016.

Sources: [5] [6] [28].

Note: Following [29] IPP price was estimated by using the following learning equation: 
International Journal of Managing Information Technology (IJMIT) Vol.10, No.3, August 2018

Finland $p_{i F}=55.3 J^{0.60}$, Singapore: $p_{i S}=46.5 J^{0.75}$ where $p_{i:}$ Index $(2000=100), J$ : Internet dependence $(\%)$.

Based on equation (4), Fig. 9 illustrates correlation between IPP/Internet price ratio and Internet/IPP ratio in Finland and Singapore over the period 2000-2017. Here, IPP implies GSC share out of GC and Internet implies the Internet dependence.

In order to gain a general idea on the possibility of soft innovation resources substitution for IPP, Fig. 10 illustrates trend in R\&D funding (which shares majority of IPP) in Singapore and Finland over the same period as Fig. 9. Looking at Figs. 9 and 10 we note that while R\&D demonstrates declining trend in Finland in recent years, its Internet/IPP ratio demonstrates sharp increase and opposite trends is observed in Singapore. These observations suggest a possible soft innovation resources substitution for IPP in Finland and their complement in Singapore

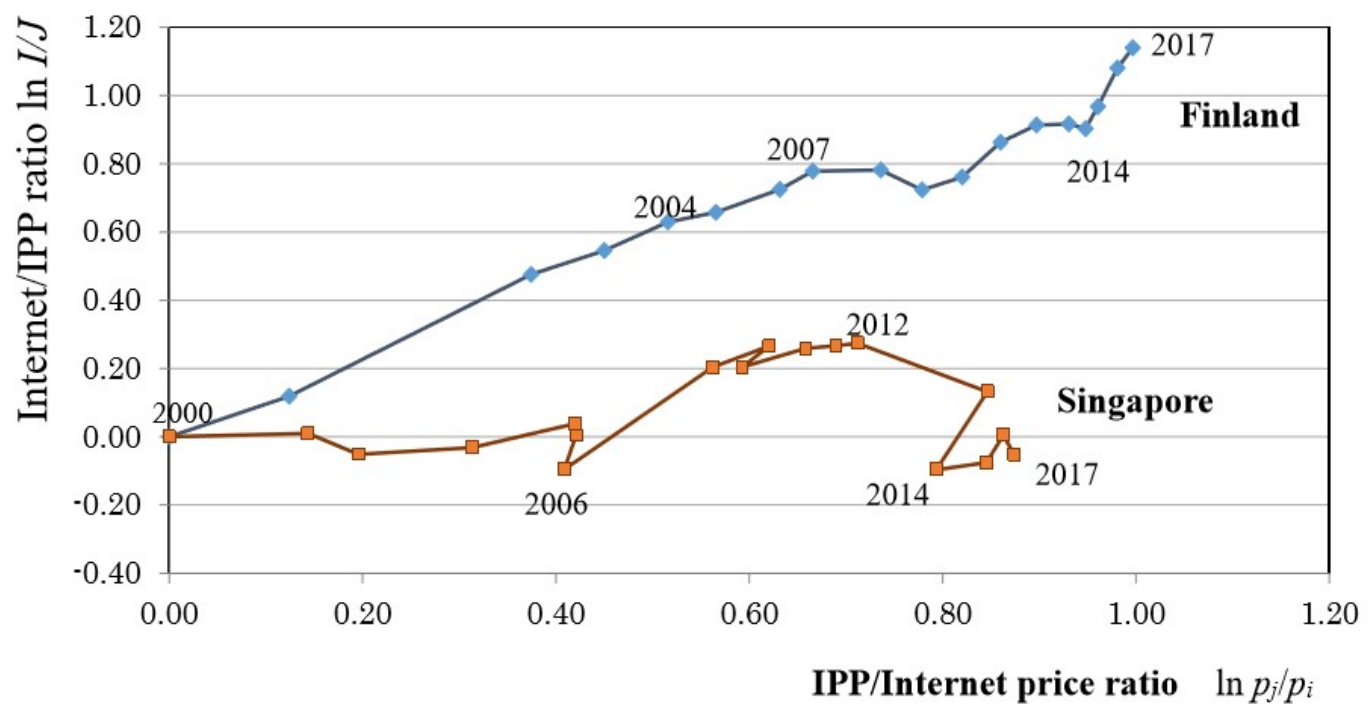

Figure 9. Correlation between IPP/Internet price ratio and Internet/IPP ratio in Finland and Singapore (2000-2017).

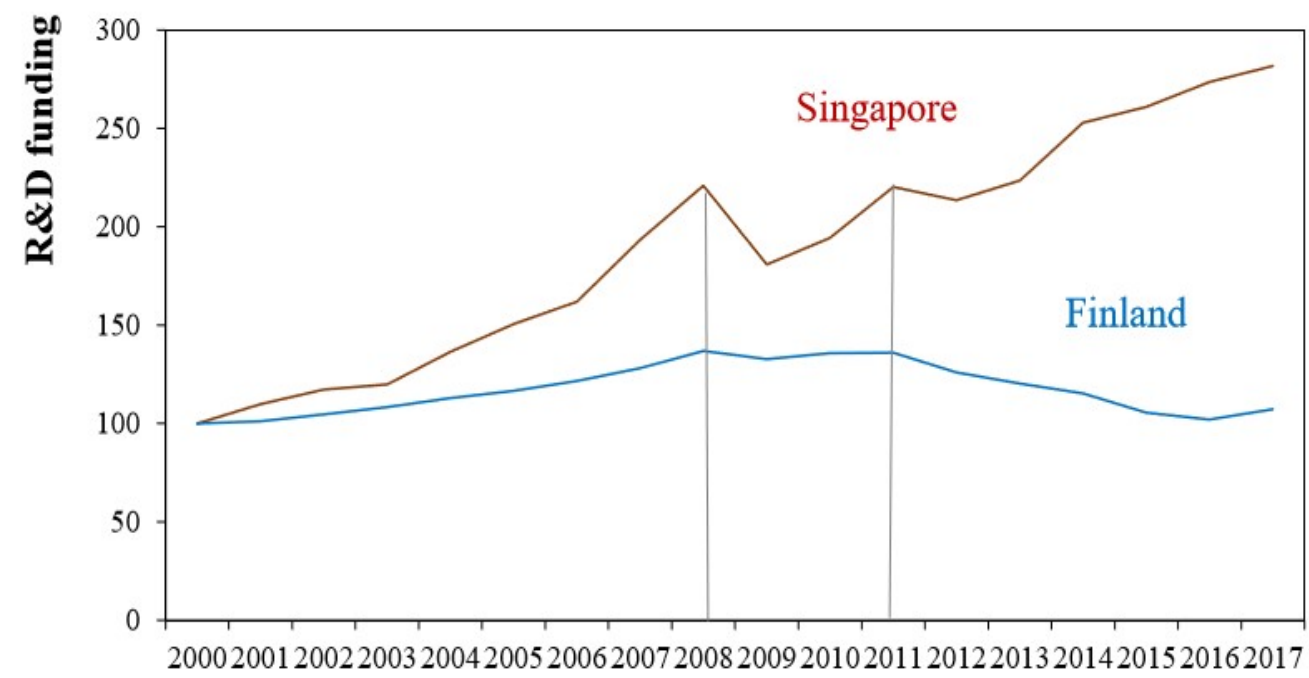

Figure 10. Trend in R\&D funding in Singapore and Finland (2000-2017) - Index: $2000=100$. Source: [19]. 
International Journal of Managing Information Technology (IJMIT) Vol.10, No.3, August 2018

Note: 2017 value for Finland is estimated by [30].

2015-2017 values for Singapore are estimated by [31] [32].

With such pre-estimation in mind, Table 6 demonstrates the result of the correlation analysis between IPP/Internet price ratio and Internet/IPP ratio in Finland and Singapore over the period 2000-2017. The result demonstrates statistically significant.

Table 6. Correlation between $p_{j} p_{i}$ and $I / J$ in Finland and Singapore (2000-2017)

\section{Finland}

$$
\begin{aligned}
& \ln \frac{l}{J}=0.087+0.952 D_{1} \ln \frac{p_{j}}{p_{i}}+4.926 D_{2} \ln \frac{p_{j}}{p_{i}}-3.818 D_{l}+0.087 D_{3} \quad \text { adj. } R^{2} 0.969 \\
& \begin{array}{lllllll}
(2.18) & (18.55) & (3.54) & (-2.83) & (2.18) & D W & 1.24
\end{array}
\end{aligned}
$$

D: Dummy variables

$$
D_{l}: 2000-2014=1,2015-2017=0 ; D_{2}: 2000-2014=0,2015-2017=1 ; D_{3}: 2004,2007=1 \text {, }
$$

others $=0$.

\section{Singapore}

$$
\begin{aligned}
& \ln \frac{l}{J}=-0.101+0.494 D_{1} \ln \frac{p_{j}}{p_{i}}-1.609 D_{2} \ln \frac{p_{j}}{p_{i}}+1.516 D_{2}-0.196 D_{3}-0.183 D_{4} \quad \text { adj. } R^{2} 0.746 \\
& \begin{array}{llllllll}
(-2.22) & (5.15) & (-3.10)) & (3.52) & (-2.67) & (-3.01) & D W & 1.20
\end{array}
\end{aligned}
$$

D: Dummy variables

$D_{1}: 2000-2011=1,2012-2017=0 ; D_{2}: 2000-2011=0,2012-2017=1 ; D_{3}: 2006=1$, others $=0$

$D_{4}:$ 2014-2015 $=1$, others $=0$.

The figures in parentheses indicate t-statistics: All are significant at the $1 \%$ level.

Table 7 compares elasticities of substitution between Internet and IPP in two countries depending on periods.

Finland maintained positive correlation for whole period examined and demonstrated strong soft innovation resources substitution for IPP from 2015. This strong substitution corresponds to its resurgence in GDP growth.

Contrary to Finland's conspicuous substitution in recent years, Singapore demonstrates opposite and demonstrates still clinging to IPP rather than soft innovation resources as clearly observed in Fig. 10.

Table 7. Elasticity of substitution between Internet and IPP in Finland and Singapore (2000-2017) 
International Journal of Managing Information Technology (IJMIT) Vol.10, No.3, August 2018

\begin{tabular}{|c|c|c|c|}
\cline { 2 - 2 } \multicolumn{1}{c|}{} & Finland & & Singapore \\
\hline $2000-2014$ & 0.952 & $2000-2011$ & 0.494 \\
\hline $2015-2017$ & 4.926 & $2012-2017$ & -1.609 \\
\hline
\end{tabular}

This result demonstrates a hypothetical view that Finland resurgent in GDP growth through gross fixed capital formation notwithstanding increasing burden of R\&D investment can largely be attributed to soft innovation resources substitution for IPP.

\section{Dissemination Of Soft InNOVATiOn Resources In TANGible CAPITAL}

Increasing dependency on soft innovation resources as substitute for IPP in Finland has disseminated steadily in gross tangible capital and removed structural impediments in its formation and enabled sustainable increase in gross fixed capital formation leading to captured GDP resurgence in recent years.

In order to confirm this effect Table 8 first compared the impact of the Internet dependence (a proxy of soft innovation resources) on gross tangible capital formation in Finland and Singapore over the period 2000-2017.

Table 8 Impact of the Internet dependence on gross tangible capital formation in Finland and Singapore (2000-2017)

\section{Finland}

$$
\begin{array}{cccccc}
\ln K_{F}=4.512+0.017 D_{1} \ln I_{F}+0.046 D_{2} \ln I_{F}+0.018 D_{3}-0.022 D_{4} & \text { adj. } R_{2} & 0.870 & D W 2.23
\end{array}
$$

$K_{F}$ : gross tangible capital ratio; $I_{F}$ : Internet dependence.

$D$ : dummy variables $D_{1}: 2000-2012=1,2013-2017=1 ; D_{2}: 2000-2012=0,2013-2017=1$; $D_{3}: 2016,2017=1$, others $=0 ; D_{4}: 2009,2010=1$, others $=0$.

\section{Singapore}

$\ln K_{S}=4.969-0.082 D_{l} \ln I_{F}-0.094 D_{2} \ln I_{F} \quad$ adj. $R_{2} \quad 0.853 \quad D W 1.55$

(41.99) (-3.53)

$K s$ : gross tangible capital ratio; $I_{s}$ : Internet dependence.

$D$ : dummy variables $D_{l}: \mathbf{2 0 0 0 - 2 0 1 2}=1,2013-2017=1 ; D_{2}: 2000-2012=0,2013-2017=1$.

The figures in parentheses indicate t-statistics: All are significant at the $1 \%$ level except *: at the $15 \%$ level.

Looking at Table 8 we note that while Finland depended on soft innovation resources (proxied by the Internet dependence), particularly largely on them after 2013, Singapore reacted negative as dependence on soft innovation resources decrease gross tangible capital formation. 
This finding suggests that in Finland soft innovation resources that substituted for IPP disseminated and spilled-over into gross tangible capital. This disseminated soft innovation resources are considered to removed structural impediments that impeded gross tangible capital formation and contributed to Finland's resurgence in GDP growth in recent years.

This resurgence is expected to resurge decreased IPP for next generation digital innovation [21] [25].

Inspired by this finding Fig. 11 demonstrates Finland's success in removing structural impediments impeding gross tangible capital formation by means of effective utilization of soft innovation resources in recent years.

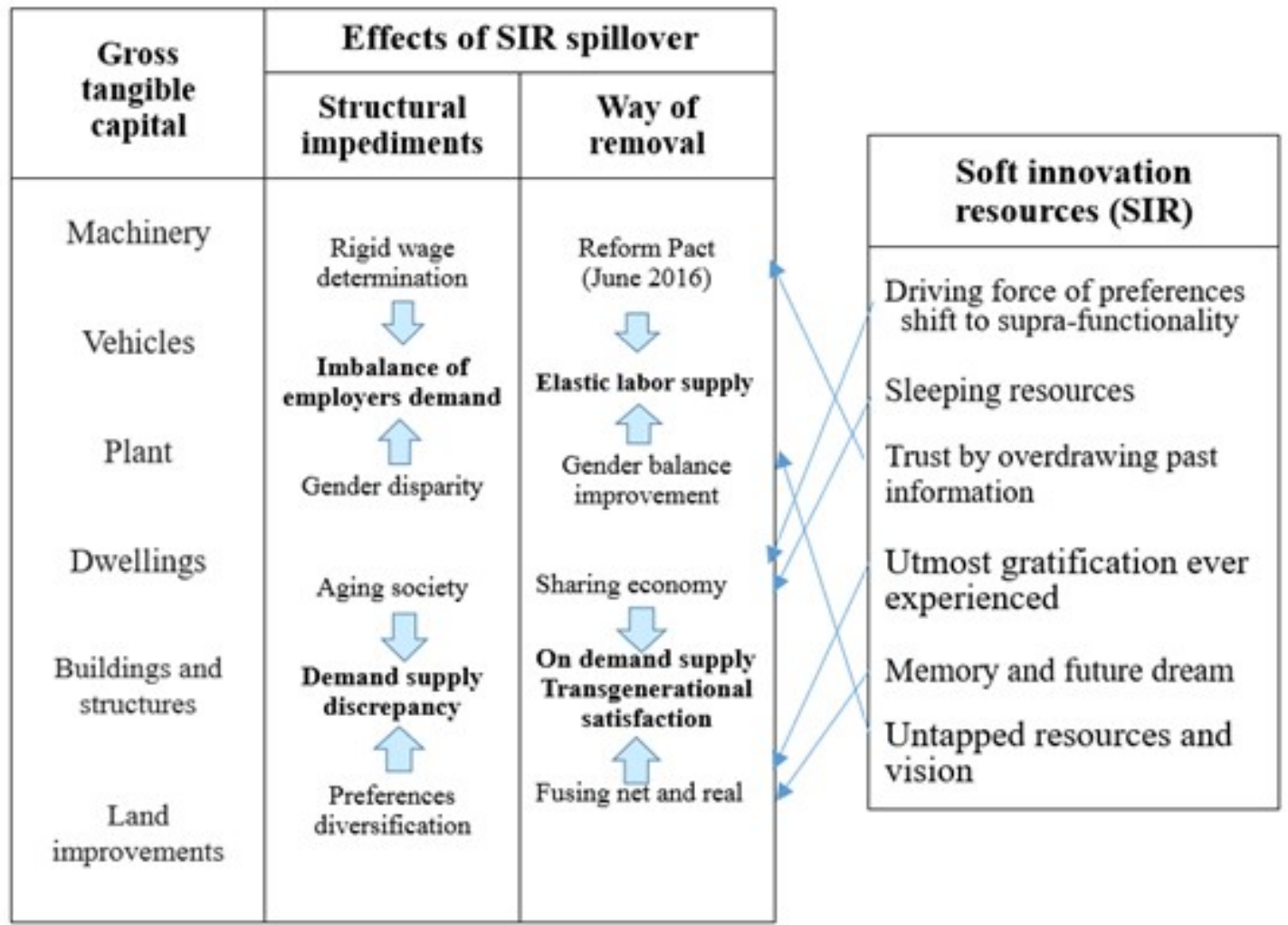

Figure 11. Effects of soft innovation resources spillover.

While Finland had the most rigid wage negotiation system in the world that impeded its growth and competitiveness for long years, government's historic ambitious decision, Reform Pact in June 2016 has relaxed this rigid system by shifting away from centralized wage-setting toward company-level labor deals and removed long-lasting impediments in growth and competitiveness. This can largely be appreciated as a consequence of effective utilization of soft innovation resource, trust (Fig. 6-3). Success in constructing coevolution between ICT development and promotion and activation of female potential in business (Fig. 6-6) can also be attributed to utilization of soft innovation resources, untapped resources. 
International Journal of Managing Information Technology (IJMIT) Vol.10, No.3, August 2018

As a consequent of such efforts, demand-supply discrepancy has dramatically decreased [33] and enabled gross tangible capital positive contribution to GDP growth. For example, machinery and equipment has changed from long lasting negative contribution to positive contribution to GDP growth from 2016 as: $-0.06 \%$ (2013), $-0.04 \%$ (2014), $-0.03 \%$ (2015) to $0.05 \%$ in 2016 [34]. Recent policy decisions of relaxation of car inspection laws (May 2018) and taxi market liberalization (July 2018) accelerate effective utilization of such soft innovation resources as driving force of preferences shift to supra-functionality (Fig. 6-1) and sleeping resources (Fig. 62). These decisions are expected to remove demand supply discrepancy toward the aging society and people's preferences diversification and enable on demand supply and transgenerational satisfaction.

\section{Conclusion}

In light of a noteworthy contrast in the world ICT leaders as high welfare with low GDP growth in Finland and higher GDP growth with lower welfare in Singapore, an uncaptured GDP postulate that Finnish wellbeing has developed more than one might conclude by GDP was provoked. In addition, the possibility that uncaptured GDP contributes to remove structural impediments in GDP growth was postulated by a recent reversal trend in the GDP growth.

This paper attempted to demonstrate these hypotheses. An empirical analysis elucidating the inside the national accountings and institutional systems in world ICT leaders Finland and Singapore was conducted.

Noteworthy findings include:

(i) Finland's recent GDP growth recovery can largely be attributed to its gross fixed capital formation.

(ii) This formation depends on gross tangible capital while gross service capital (IPP) contributes to negative.

(iii) This is due to substitution of soft innovation resources for service capital in Finland.

(iv) This substitution creates uncaptured GDP which disseminates in tangible capital and removes structural impediments impeding tangible capital formation.

(v) This removal leads to resurgence of GDP growth.

(vi) In addition, this growth enables next generation IPP.

These findings give rise to the following insightful suggestions for optimal trajectory management in the digital economy both national and firm levels:

(i) Further exploration and utilization of soft innovation resources should be continued.

(ii) Effective mechanism of soft innovation resources substitution for IPP should be developed.

(iii) Optimal balance between soft innovation resources dependence and sustainable IPP should be sought.

(iv) Effective dissemination of soft innovation resources-driven uncaptured GDP into gross tangible capital should be developed.

(v) Similar substitution mechanism in consumption should be analyzed.

An insightful suggestion in overcoming a productivity paradox in the digital economy was thus provided.

Future works should focus on further international comparisons. In addition, careful monitoring of the reversal trend should be continued. 
International Journal of Managing Information Technology (IJMIT) Vol.10, No.3, August 2018

\section{ACKNOWLEDGEMENTS}

The research leading to these results is the part of a project: Platform Value Now: Value capturing in the fast emerging platform ecosystems, supported by the Strategic Research Council at the Academy of Finland [grant number 293446].

\section{REFERENCES}

[1] Ylhainen, I., (2017) Challenges of Measuring the Digital Economy. https://www.sitra.fi/en/articles/challenges-measuring-digital-economy/

[2] Watanabe, C., Moriya, K., Tou, Y. \& Neittaanmäki, P., (2018b) "Consequences of the Digital Economy: Transformation of the Growth Concept," International Journal of Managing Information Technology, Vol. 10, No. 2, pp 21-39.

[3] IMF, (2017) "World economic outlook database," IMF, Washington.

[4] Watanabe, C., Tou, Y. \& Neittaanmäki, P., (2018c) "A New Paradox of the Digital Economy: Structural Sources of the Limitation of GDP Statistics," Technology in Society, in print.

[5] Statistics Finland, (2018a) "National accounts of Finland," Statistics Finland, Helsinki.

[6] Department of Statistics Singapore, (2018a) "National Accounts of Singapore," Department of Statistics Singapore, Singapore.

[7] Watanabe, C., Moriya, K., Tou, Y. \& Neittaanmäki, P., (2018a) "Structural Sources of a Productivity Decline in the Digital Economy," International Journal of Managing Information Technology, Vol. 10, No. 1, pp 1-20.

[8] Naveed, K., Watanabe, C. \& Neittaanmäki, P., (2018) "The Transformative Direction of Innovation toward an IoT-based Society: Increasing Dependency on Uncaptured GDP in Global ICT Firms," Technology in Society, Vol. 53, pp 23-46.

[9] Watanabe, C., Kondo, R., Ouchi, N., Wei, H. and Griffy-Brown, C., (2004) "Institutional Elasticity as a Significant Driver of IT Functionality Development," Technological Forecasting and Social Change, Vol. 71, No. 7, pp 723-750.

[10] Bharadwaj, A., Sawy, O.A.E., Pavloyu, P.A. and Venkatraman, N. (2013) "Digital Business Strategy: Toward a Next Generation of Insights," MIS Quarterly, Vol. 37, No. 2, 471-482.

[11] McKinsey Global Institute. (2015) The Internet of Things: Mapping the Value beyond the Hype. McKinsey \& Company, San Francisco.

[12] Internet Society, Internet Report 2016, https://www.internetsociety.org/globalinternetreport/2016/wpcontent/uploads/2016/11/ISOC_GIR_2016-v1.pdf, 2016 (retrieved 05.08.2017).

[13] Watanabe, C., Naveed, K., Neittaanmäki, P. \& Tou, Y., (2016a) "Co-evolution of Three Mega Trends Nature Uncaptured GDP: Uber's Ride-sharing Revolution,” Technology in Society, Vol. 46, pp 164 185.

[14] Watanabe, C., Naveed, K. \& Neittaanmäki, P., (2016b) "Co-evolution between Trust in Teachers and Higher Education toward Digitally-rich Learning Environments," Technology in Society, Vol. 48, pp 70-96.

[15] Watanabe, C., (2013) "Innovation-consumption Co-emergence Leads a Resilience Business," Innovation and Supply Chain Management, Vol. 7, No. 3, pp 92-104.

[16] Naveed, K., Watanabe, C. \& Neittaanmäki, P., (2017) "Co-evolution between Streaming and Live Music Leads a Way to the Sustainable Growth of Music Industry: Lessons from the US Experiences," Technology in Society, Vol. 50, pp 1-19.

[17] Watanabe, C., Naveed, K. \& Neittaanmäki,P., (2017) "ICT-driven Disruptive Innovation Nurtures Uncaptured GDP: Harnessing Woemen's Potential as Untapped Resources," Technology in Society, Vol. 51, pp 81-101.

[18] OECD, (2017) "OECD Review of innovation policy: Finland assessment and recommendation," OECD, Paris. 
International Journal of Managing Information Technology (IJMIT) Vol.10, No.3, August 2018

[19] OECD, (2018) "OECD database," OECD, Paris.

[20] Ministry of Finance Singapore, (2018). Singapore Budget 2018. Ministry of Finance Singapore, Singapore.

[21] Hutchenreiter, G., Zuniga, P. \& Weber J., (2017). "OECD Review of Innovation Policy: Finland Assessment and Recommendations," Launch Seminar, Helsinki.

[22] Watanabe, C., Naveed, K. \& Neittaanmäki, P., (2015b) "Dependency on Un-captured GDP as a Source of Resilience beyond Economic Value in Countries with Advanced ICT Infrastructure: Similarities and Disparities between Finland and Singapore," Technology in Society, Vol. 42, pp $104-122$.

[23] Ministry of Employment and the Economy (MEE), (2008) "Finland's National Innovation Strategy," MEE, Helsinki.

[24] Hautamaki, A., (2017). "Finland's Research and Innovation Policy Needs to be Revised with a Broad Brush," Business \& Finance, Politics, Tech \& Science.

[25] Zubascu. F., (2017) "Finland Remodels Its Innovation Strategy,” Science \& Business.

[26] Ministry of Economic Affairs and Employment of Finland (MEAE), (2017) "Finland's Preliminary Views on the EU's 9th Framework Programme (2021-) for Research and Innovation," MEAE, Helsinki.

[27] Ministry of Economic Affairs and Employment of Finland (MEAE), (2018) "Innovation Policy Provides an Incentive for Continuous Renewal," MEAE, Helsinki. http://tem.fi/en/innovation-policy Retrieved 6 April 2018.

[28] International Telecommunication Union (ITU), (2018) "World telecommunication/ICT indicators database, " ITU, Geneva.

[29] Watanabe, C., Naveed, K. \& Zhao, W., (2015a) "New Paradigm of ICT Productivity: Increasing Role of Un-captured GDP and Growing Anger of Consumers," Technology in Society, Vol. 41, pp 21-44.

[30] Statistics Finland, (2018b). "Government Budget Allocation for R\&D in 2018." Statistics Finland, Helsinki.

[31] Department of Statistics Singapore, (2018b) "Detailed Statistical Time Series, R\&D Expenditure," Department of Statistics Singapore, Singapore.

[32] Ministry of Finance Singapore, (2018) "Singapore budget 2018)," Ministry of Singapore, Singapore.

[33] Statistics Finland, (2018c). "The Labor Market in Finland," Statistics Finland, Helsinki.

[34] Statistics Finland, (2018d). "Statistics Finland's PX-Web databases," Statistics Finland, Helsinki.

\section{AuTHORS}

Yuji Tou graduated from Tokyo Institute of Technology, Japan, and is currently specially appointed associate professor at Tokyo Institute of Technology, Japan (tou.yuji@gmail.com).

Kuniko Moriya graduated from Aoyama Gakuin University, Japan, and is currently Director of the Bank of Japan, and a research scholar at the University of Jyväskylä, Finland (kuniko.moriya@boj.or.jp).

Chihiro Watanabe graduated from the University of Tokyo, Japan, and is currently Professor Emeritus at the Tokyo Institute of Technology, research professor at the University of Jyväskylä, Finland, and a research scholar at the International Institute for Applied Systems Analysis (IIASA). (watanabe.c.pqr@gmail.com).

Leena Ilmola graduated from Aalto University School of Science and Technology, Finland, and now is currently Senior Researcher at the International Institute of Technology (IIASA), Austria (ilmola@iiasa.ac.at)

Pekka Neittaanmäki graduated from the University of Jyväskylä with a degree in Mathematics. He is currently Professor of the Faculty of Information Technology, University of Jyväskylä, Finland. (pekka.neittaanmaki@jyu.fi). 